\title{
TOLAK UKUR PERBANDINGAN NEGARA INDONESIA 4.0 (FOUR POINT ZERO) DENGAN NEGARA 5.0 (FIVE POINT ZERO)
}

\author{
Ida Rahma \\ Sekolah Tinggi Agama Islam Negeri ( STAIN ) Teungku Dirundeng Meulaboh \\ yudiansyahsh1983@gmail.com
}

\begin{abstract}
ABSTRAK
Dampak revolusi industri 4.0 dan society 5.0 membuka peluang baru bagi Indonesia. Revolusi industri 4.0 justru memberikan peluang bagi Indonesia untuk berinovasi. Revolusi yang berfokus pada pengembangan ekonomi digital dipandang bermanfaat bagi Indonesia. Perkembangan ekonomi digital adalah pasar dan talenta, dan Indonesia memiliki keduanya. Indonesia berkomitmen mengembangkan industri manufaktur yang berdaya saing global melalui percepatan industri 4.0, hal ini ditandai dengan diluncurkannya Making Indonesia 4.0 sebagai peta jalan dan strategi Indonesia memasuki era digital yang sedang berlangsung. Penyusunan road map ini telah melibatkan berbagai pemangku kepentingan, mulai dari instansi pemerintah, pelaku usaha, asosiasi industri, penyedia teknologi, serta lembaga penelitian dan pendidikan. Melalui komitmen dan partisipasi aktif dari semua pihak tersebut, dapat dipastikan implementasi Industri 4.0 di Indonesia akan berhasil dan tepat sasaran. Fokus yang datang dari society 5.0 menjadi peluang besar bagi Indonesia untuk mempercepat transformasi masyarakatnya. Bagi Indonesia ini bukan soal berdiri di atas dua kaki, Revolusi Industri 4.0 dan society 5.0., sebaliknya kedua momentum ini harus digabungkan menjadi cetak biru nasional.
\end{abstract}

Kata kunci: Tolok Ukur, Perbandingan, Revolusi Industri, 4.0 dan 5.0

\begin{abstract}
The impact of the industrial revolution 4.0 and Society 5.0 created new opportunities for Indonesia. The 4.0 industrial revolution actually provided an opportunity for Indonesia to innovate. A revolution focused on developing the digital economy is seen as beneficial for Indonesia. Digital economic development is a market and talent, and Indonesia has both. Indonesia is committed to developing a manufacturing industry that is globally competitive through the acceleration of industry 4.0, this is marked by the launch of Making Indonesia 4.0 as a road map and Indonesia's strategy to enter the digital era that is currently underway. The preparation of this road map has involved various stakeholders, ranging from government institutions, business actors, industry associations, technology providers, as well as research and education institutions. Through the commitment and active participation of all these parties, it is certain that the implementation of Industry 4.0 in Indonesia will be successful and on target. The focus that came from Society 5.0 became a great opportunity for Indonesia to accelerate the transformation of its society. For Indonesia it is not a matter of immediately standing on two legs, the Industrial Revolution 4.0 and society 5.0. instead these two momentum must be combined into a national blueprint.
\end{abstract}

Keyword: Benchmarks, Comparisons, Industrial revolutions, 4.0 and 5.0 
Jurnal Sosial Humaniora Sigli (JSH)

p ISSN : 2615-3688

$e$ ISSN : 2716-0270

http://journal.unigha.ac.id/index.php/JSH

\section{Pendahuluan}

Revolusi industri merupakan sebuah perubahan cara hidup manusia dan proses kerja secara fundamental, dimana adanya kemajuan teknologi informasi dapat mengintegrasikan dalam dunia kehidupan dengan digital yang dapat memberikan dampak disiplin ilmu. Munculnya revolusi industri 4.0 membut wajah baru dalam fase kemajuan teknologi.

Pada revolusi industri 4.0, teknologi manufaktur sudah masuk pada tren otomasi dan pertukaran data. Hal tersebut mencakup sistem cyber-fisik, internet of things (IoT), komputasi awan, dan komputasi kognitif. Dengan lahirnya teknologi digital saat ini pada revolusi industri 4.0 berdampak terhadap kehidupan manusia diseluruh dunia.

Menurut Tjandrawinata (2016), perkembangan teknologi informasi dengan pesat saat ini terjadi otomotisasi yang terjadi diseluruh bidang, teknologi dan pendekatan baru yang menggabungkan secara nyata, digital dan secara fundamental.

Revolusi industri 4.0 ini terdapat beberapa tantangan yang dihadapi yaitu kurangnya keterampilan yang memadai, masalah kemanan teknologi komunikasi, keandalan stabilitas mesin produksi, ketidak mampuan untuk berubah oleh pemangku kepentingan, serta banyaknya kehilangan pekerjaan karena berubah menjadi otomasi.

Teknologi ini berdampak positif tergantung bagaimana individu dalam meminimalisir resiko dan peluang yang muncul di transformasi revolusi industri 4.0 yang terjadi berbeda dengan apa yang dialami manusia sebelumnya.

Disisi lain, Negara Jepang menyatakan dunia ini akan memasuki era Society 5.0 atau masyarakat 5.0 dimana, masyarakat yang berpusat pada manusia (humancentered) yang dikembangkan oleh Jepang.
Menurut Kantor Kabinet Jepang, Society 5.0 didefinisikan sebagai sebuah masyarakat yang berpusat pada manusia yang menyeimbangkan kemajuan ekonomi dengan penyelesaian masalah sosial melalui sistem yang sangat mengintegrasikan ruang maya dan ruan fisik.

Revolusi industri 4.0 yang dinilai berpotensi dalam mendegradasi peran manusia membuat Jepang melahirkan sebuah konsep yaitu Society 5.0. Melalui konsep ini diharapkan membuat kecerdasan buatan akan mentransformasi big data yang dikumpulkan melalui internet pada segala bidang kehidupan menjadi suatu kearifan yang baru, dengan harapan untuk meningkatkan kemampuan manusia dalam membuka peluang-peluang bagi manusia.

Perbandingan dari kedua konsep ini yaitu pada industri 4.0, masyarakat mencari, mengutip, dan menganalisis dta atau informasi dengan mengakses layanan cloud melalui internet.

Sedangkan, pada Society 5.0 sejumlah besar informasi dari sensor di ruang fisik terakumulasi di dunia maya dan dianalisis oleh kecerdasan buatan, dan hasilnya diumpan kembali ke manusia dalam ruang fisik dalam berbagai bentuk.

Dampak dari revolusi industri 4.0 dan Society 5.0 membuat kesempatan baru untuk Indonesia. Menurut Menteri Perindustrian Airlangga Hartanto, revolusi industri 4.0 justru memberi kesempatan bagi Indonesia untuk berinovasi. Revolusi yang fokus pada pengembangan ekonomi digital dinilai menguntungkan bagi Indonesia. Pengembangan ekonomi digital adalah pasar dan bakat, dan Indonesia memiliki keduanya.

Indonesia berkomitmen untuk membangun industri manufaktur yang berdaya saing global melalui percepatan industri 4.0, hal ini ditandai dengan 
peluncuran Making Indonesia 4.0 sebagai sebuah peta jalan dan strategi Inonesia memasuki era digital yang tengah berjalan saat ini.

Making Indonesia 4.0 dapat memberikan arah yang jelas bagi pergerakan industri nasional di masa depan, terasuk fokus pada pengembangan lima sektor manufaktur yang akan menjadi percontohan.

Pada penyusunan peta jalan ini telah melibatkan berbagai pemangku kepentingan, mulai dari Institusi Pemerintahan, pelaku usaha, asosiasi industri, penyedia teknologi, maupun lembaga riset dan pendidikan. Malalui komitmen serta partisipasi aktif dari seluruh pihak tersebut, dapat diyakini implementasi Industri 4.0 di Indonesia akan berjalan sukses dan sesuai sasaran.

Pada penerapan awal terdapat lima industri yang menjadi fokus implementasi industri 4.0 di Indonesia, yaitu :

1.Makanan dan minuman

2. Tekstil

3. Otomotif

4. Elektronik

5. Kimia

Kelima industri ini merupakan tulang punggung, dan diharapkan membawa pengaruh yang besar dalam hal daya saing dan kontribusinya terhadap ekonomi Indonesia menuju 10 besar ekonomi dunia di 2030.

Hal ini lah yang akan menjai contoh bagi penerapan industri 4.0, penciptaan lapangan kerja baru dan investasi baru berbasis teknologi. Kemudian, menarik minat investasi asing, peningkatan kualitas sumber daya manusia, (SDM) pembangunan ekosistem inovasi, insentif untuk investasi teknologi, serta harmonisasi aturan dan kebijakan.

Dalam hal ini, dengan adanya manfaat yang nyata, Indonesia berkomitmen dengan kuat untuk mengimplementasikan Making Indonesia 4.0 dan menjadikannya sebagai agenda nasional. Perlu diingat juga pada konsep ini ditengah dunia berfokus pada Industri 4.0 (Penggunaan Teknologi, Data, dan Automation), terdapat sentuhan humanisme di dalam Society 5.0 akan menjadi modal dasar konsep ini akan diterima oleh masyarakat Indonesia bahkan dunia.

Fokus yang menjadi dari dalam Society 5.0 menjadi peluang besar bagi Indonsia untuk mempercepat transformasi masyarakatnya. Bagi Indonesia tidak masalah langsung berpijak pada dua kaki, Revolusi industri 4.0 dan society 5.0. justru kedua momentum ini harus digabungkan menjadi blue print nasional.

Harus tercipta kesadaran bersama baik oleh pemerintah, dunia usaha maupun masyarakat, mulai dari mengubah pikiran negatif dan ketakutan terhadap perkembangan industri serta paradigma jika teknologi itu sulit, bahwa perubahan besar dalam industri adalah keniscayaan yang tidak bisa dihindari.

\section{Metode Penelitian}

Penelitian ini mengunakan penelitian analisis kualitatif-deskriptif dengan mengunakan teknik library research (studi pustaka). Metode penelitian ini mengunakan pendekatan normatif dan sosiologi pengetahuan. Penelitian normatif digunakan untuk mengkaji tentang Tolak Ukur perbandingan Negara Indonesia 4.0 dan 5.0. Sedangkan pendekatan sosiologis pengetahuan digunakan untuk mengamati dan menganalisis fakta-fakta empiris dilapangan yang didapat dari bahan pustaka yang relavan dengan pokok bahasan.

Analisis data yang digunakan dalam penelitian ini mengunakan deskriptifkualitatif. Masalah atau fakta yang dipaparkan secara deskriptif, kemudian dianalisis guna memperoleh gambaran yang utuh tentang permasalahan-permasalahan yang diteliti, termasuk dengan melakukan analisi isi (contect analysis). Penelitian deskriptif kualitatif yaitu sebuah penelitian yang berusaha mengungkapkan keadaan yang bersifat alamiah secara holistik. 
Jurnal Sosial Humaniora Sigli (JSH)

p ISSN : 2615-3688

$e$ ISSN : 2716-0270

http://journal.unigha.ac.id/index.php/JSH

Penelitian kualitatif bukan hanya menggambarkan variabel-variabel tunggal melainkan dapat mengungkapkan hubungan antara satu variabel dengan variabel yang lainnya.

Dari analisis terhadap hubungan antar variabel diatas maka dapat diambil suatu kesimpulan yang relavan untuk diterapkan tampa harus merugikan variabel lainnya dan justru harapannya dapat memberi kontribusi yang baik untuk tiap variabel yang dianalisi.

Dengan harapan, penelitian ini dapat berdampak langsung bagi masyarakat, dan bagi pemerintah.

\section{Pembahasan}

Definisi mengenai Industri 4.0 beragam karena masih dalam tahap penelitian dan pengembangan. Kanselir Jerman, Angela Merkel (2014) berpendapat bahwa Industri 4.0 adalah transformasi komprehensif dari keseluruhan aspek produksi di industri melalui penggabungan teknologi digital dan internet dengan industri konvensional. Schlechtendahl dkk (2015) menekankan definisi kepada unsur kecepatan dari ketersediaan informasi, yaitu sebuah lingkungan industri di mana seluruh entitasnya selalu terhubung dan mampu berbagi informasi satu dengan yang lain.

Pengertian yang lebih teknis disampaikan oleh Kagermann dkk (2013) bahwa Industri 4.0 adalah integrasi dari Cyber Physical System (CPS) dan Internet of Things and Services (IoT dan IoS) ke dalam proses industri meliputi manufaktur dan logistik serta proses lainnya. CPS adalah teknologi untuk menggabungkan antara dunia nyata dengan dunia maya. Penggabungan ini dapat terwujud melalui integrasi antara proses fisik dan komputasi (teknologi embedded computers dan jaringan) secara close loop (Lee, 2008). Hermann dkk (2015) menambahkan bahwa Industri 4.0 adalah istilah untuk menyebut sekumpulan teknologi dan organisasi rantai nilai berupa smart factory, CPS, IoT dan IoS. Smart factory adalah pabrik modular dengan teknologi CPS yang memonitor proses fisik produksi kemudian menampilkannya secara virtual dan melakukan desentralisasi pengambilan keputusan. Melalui IoT, CPS mampu saling berkomunikasi dan bekerja sama secara real time termasuk dengan manusia. IoS adalah semua aplikasi layanan yang dapat dimanfaatkan oleh setiap pemangku kepentingan baik secara internal maupun antar organisasi. Terdapat enam prinsip desain Industri 4.0 yaitu interoperability, virtualisasi, desentralisasi, kemampuan real time, berorientasi layanan dan bersifat modular. Berdasar beberapa penjelasan di atas, Industri 4.0 dapat diartikan sebagai era industri di mana seluruh entitas yang ada di dalamnya dapat saling berkomunikasi secara real time kapan saja dengan berlandaskan pemanfaatan teknologi internet dan CPS guna mencapai tujuan tercapainya kreasi nilai baru ataupun optimasi nilai yang sudah ada dari setiap proses di industri.

Revolusi Industry 4.0 dan Society 5.0 menurut Andreja merupakan gerakan nyata terhadap perkembangan informasi dan teknologi yang semakin canggih. Kedua revolusi tersebut sebenarnya memiliki esensi yang berbeda, akan tetapi dengan core yang sama yaitu teknologi. Pertama adalah industry 4.0 merupakan industri yang menggabungkan teknologi otomatisasi dengan teknologi cyber. Ini merupakan tren otomatisasi dan pertukaran data dalam teknologi manufaktur. Ini termasuk sistem cyber-fisik, Internet of Things (IoT), komputasi awan dan komputasi kognitif.

Menurut Agustini Revolusi indutry 4.0 juga disebut sebagai revolusi industri yang akan mengubah pola dan relasi antara manusia dengan mesin. Inovasi yang diawali dengan besarnya data di internet dan penggunaan cloud mengubah produk industri. Serta mengubah proses produksi dan pemasaran produk. Bahkan mengubah gaya hidup masyarakat karena produk dari revolusi industri ini dapat dilihat penggunaannya di kehidupan sehari-hari. 
Secara umum revolusi industri keempat ditandai dengan full automation, proses digitalisasi, dan penggunaan alat elektronik dengan sistem informatika. Hal tersebut juga akan mempengaruhi relasi antara customer dengan perusahaan, serta relasi masyarakat umum dengan pemimpin negaranya. Revolusi industry 4.0 merupakan sesuatu yang tidak dapat ditolak karena telah terlihat bahwa penggunaan berbagai macam hasil produk revolusi industy 4.0 telah dirasakan saat ini. Pada revolusi industri sebelumnya biasanya selalu didominasi oleh negara-negara Eropa dan Amerika yang memiliki berbagai modal yang lebih besar.

Akan tetapi, revolusi industy 4.0 memungkinkan setiap negara untuk mengembangkan diri dan meningkatkan kemampuannya secara internal dari segala segi bidang. Karena batas-batas negara akan semakin berkurang dengan masifnya pertukaran informasi di era digital. Indonesia secara umum berada pada posisi tengah dalam revolusi industy $4.0 \mathrm{di}$ ASEAN. Kondisi tersebut bukan berarti Indonesia harus merasa tenang, karena negara lain, seperti Malaysia, Filipina, Vietnam, dan Brunei Darussalam juga berupaya bergerak lebih cepat. Revolusi industry 4.0 memungkinkan tiap negara untuk melakukan leapfrogging. Oleh karena itu Indonesia perlu rencana yang strategis dan segera diimplementasikan Dalam rangka pelaksanaan inovasi era revolusi industri keempat, Indonesia perlu melakukan pemetaan potensi dan tantangannya. Serta merumuskan tujuan dari revolusi industy 4.0 yang akan dikembangkan.

Selanjutnya pada perkembangan era ini dibutuhkan kerja sama antara berbagai pihak, baik industri, entrepreneur, pemerintah pusat, pemerintah daerah, serta organisasi kemasyarakatan dalam merumuskan strategi Indonesia menghadapi revolusi industri 4.0.

Kedua adalah Society 5.0 yang sebenarnya juga tidak lepas dari perkembangan teknologi, akan tetapi dalam revolusi ini lebih mengarah pada tatanan kehidupan bermasyarakat, dimana setiap tantangan yang ada dapat diselesaikan melalui perpaduan inovasi dari berbagai unsur yang terdapat pada revolusi industry 4.0. Melalui Society 5.0, kecerdasan buatan yang memperhatikan sisi kemanusiaan akan mentransformasi jutaan data yang dikumpulkan melalui internet pada segala bidang kehidupan. Tentu saja diharapkan, akan menjadi suatu kearifan baru dalam tatanan bermasyarakat. Tidak dapat dipungkiri, transformasi ini akan membantu manusia untuk menjalani kehidupan yang lebih bermakna. Dalam Society 5.0, juga ditekankan perlunya keseimbangan pencapaian ekonomi dengan penyelesaian problem sosial. Society 5.0, nilai baru yang diciptakan melalui inovasi akan menghilangkan kesenjangan regional, usia, jenis kelamin, dan bahasa dan memungkinkan penyediaan produk dan layanan yang dirancang secara halus untuk beragam kebutuhan individu dan kebutuhan laten. Dengan cara ini, akan mungkin untuk mencapai masyarakat yang dapat mempromosikan pembangunan ekonomi dan menemukan solusi untuk masalah sosial. Kedua revolusi tersebut saling berkesinambungan membentuk pola tatanan kehidupan bermasyarakat, yaitu ketika setiap permasalahan dan tantangan yang terdapat didalamnya dapat diselesaikan melalui perpaduan inovasi dari berbagai unsur yang diterapkan pada revolusi industry 4.0 dan kemudian dipadukan dengan society 5.0. Hubungan tersebut diharapkan dapat berperan aktif dalam meningkatkan kualitas kehidupan sosial, sehingga setiap usaha dalam meningkatkan dan mengembangkan revolusi tersebut akan mencermintkan produk dan layanan masyarakat yang bisa diberikan secara berkelanjutan. Karakteristik di era kedua revolusi tersebut meliputi digitalisasi, optimation dan cutomization produksi, otomasi dan adaptasi, interaksi antara 
manusia dengan mesin, value added services and business, automatic data exchange and communication, serta penggunaan teknologi informasi. Oleh karen itu, dunia pendidikan tinggi vokasi yang merupakan hilir dari terbentuknya SDM yang berdaya saing global dan industri harus mampu mengembangkan starategi transformasi industri dengan mempertimbangkan sektor SDM yang memiliki kompetensi dibidangnya.

Dalam perkembangannya revolusi industy 4.0 harus direspon secara cepat dan tepat oleh seluruh pemangku kepentingan tidak terkecuali dibidanng pendidikan tinggi vokasi agar mampu meningkatkan daya saing bangsa Indonesia ditengah persaingan. Untuk itu Pendidikan Tinggi vokasi wajib merumuskan kebijakan strategis dalam berbagai aspek mulai dari kelembagaan, bidang studi, kurikulum, sumber daya, serta pengembangan cyber university, dan risbang hingga inovasi dengan tanpa tidak melepaskan nilai pancasila sebagai acuan dalam pengembangan kemampuan.

Perkembangan teknologi yang begitu pesat, termasuk adanya peran-peran manusia yang tergantikan oleh kehadiran robot cerdas, dianggap dapat mendegradasi peran manusia. Hal ini yang melatar belakangi lahirnya Society 5.0 yang diperkenalkan di Kantor Perdana Menteri Jepang pada hari Senin, 21 Januari 2019.

Melalui Society 5.0, kecerdasan buatan (artificial intelligence) akan mentransformasi big data pada segala sendi kehidupan serta the Internet of Things akan menjadi suatu kearifan baru, yang akan didedikasikan untuk meningkatkan kemampuan manusia membuka peluangpeluang bagi kemanusiaan.

Transformasi ini akan membantu manusia untuk menjalani kehidupan yang lebih bermakna.

Secara sederhana, Society 5.0 dapat diartikan sebagai suatu konsep masyarakat yang berpusat pada manusia (human- centered) dan berbasis teknologi (technology based). Contoh aplikasi yang akan diterapkan oleh pemerintah Jepan dengan adanya konsep peradaban baru ini diantaranya sebagai berikut.

\section{Masalah}

- Jepang menghadapi masalah tingginya generasi tua yang mana pengeluaran untuk biaya pengobatan serta pelayanan nya semakin meningkat

- Kemajuan Jepang membuat minimnya ketersediaan tenaga buruh ahli dan tingginya biaya perawatan infrastruktur

\section{Solusi}

- Menggunakan data medical records untuk membantu mempercepat penanganan kesehatan

- Membuat sistem remot untuk pelayanan kesehatan

- Menggunakan AI dan robot sebagai perawat

- Sensor, AI, dan robot akan digunakan untuk membantu pemeliharaan jalan, terowongan, jembatan dan infrastruktur lainnya

\section{Kesimpulan}

Dari uraian hasil penelitian diatas, dapat ditarik kesimpulan sebagai berikut :

Dampak dari revolusi industri 4.0 dan Society 5.0 membuat kesempatan baru untuk Indonesia. Indonesia berkomitmen untuk membangun industri manufaktur yang berdaya saing global melalui percepatan industri 4.0, hal ini ditandai dengan peluncuran Making Indonesia 4.0 sebagai sebuah peta jalan dan strategi Inonesia memasuki era digital yang tengah berjalan saat ini.

Dalam hal ini, dengan adanya manfaat yang nyata, Indonesia berkomitmen untuk mengimplementasikan Making Indonesia 4.0 dan menjadikannya sebagai agenda nasional. Perlu diingat juga pada konsep ini ditengah dunia berfokus pada Industri 4.0 
Jurnal Sosial Humaniora Sigli (JSH)

p ISSN : 2615-3688

$e$ ISSN : 2716-0270

http://journal.unigha.ac.id/index.php/JSH

(Penggunaan Teknologi, Data, dan Automation), terdapat sentuhan humanisme di dalam Society 5.0 akan menjadi modal dasar konsep ini akan diterima oleh masyarakat Indonesia bahkan dunia.

Artikel ini menyajikan hasil studi terhadap aspek dan arah perkembangan riset Industri 4.0. Berdasar hasil studi, ditemukan empat belas aspek yang ada pada Industri 4.0. Penelusuran data publikasi telah dilaksanakan untuk mengetahui arah perkembangan riset Industri 4.0. Ditinjau dari metode penelitian, sebagian besar riset dilakukan melalui metode deskriptif dan konseptual. Ditinjau dari aspeknya, aspek bisnis dan teknologi masih menjadi fokus riset para peneliti. Ditinjau dari bidang industri penerapannya, sebagian besar riset dilakukan di bidang manufaktur. Ditinjau dari jumlahnya, riset terkait Industri 4.0 mengalami tren kenaikan yang signifikan. Hasil tersebut menunjukkan bahwa posisi riset Industri 4.0 saat ini berada pada tahap pematangan konsep yang bertujuan agar konsep Industri 4.0 dapat diterapkan secara global tidak hanya di negara maju namun juga negara-negara berkembang. Seiring semakin matangnya konsep Industri 4.0 secara global, riset dengan metode terapan dan empiris diprediksi akan semakin berkembang guna menjawab tantangan realisasi teknologi Industri 4.0. Riset dengan aspek kajian bisnis dan teknologi di bidang manufaktur diprediksi akan menjadi fokus arah pengembangan. Hasil prediksi tersebut mendorong para akademisi agar lebih meningkatkan kerjasama dengan industri manufaktur. Pola kerjasama antara dunia akademik dan industri sangat diperlukan untuk mempercepat realisasi Industri 4.0. Tren peningkatan jumlah riset tiap tahunnya menjadi bukti bahwa para akademisi mulai mengarahkan fokus risetnya pada Industri 4.0. Kondisi ini perlu diperhatikan oleh dunia pendidikan terutama di negara-negara berkembang agar segera tanggap terhadap perubahan yang terjadi dan mempersiapkan sumber daya yang dimiliki dalam rangka menghadapi tren Industri.

Di sisi lain, Industri 4.0 diprediksi akan membawa dampak negatif terutama dari sudut pandang sosial dan ekonomi. Dampak ini rentan terjadi terutama pada negara-negara berkembang yang tingkat kesenjangan sosial dan ekonominya masih relatif tinggi. $\mathrm{Ke}$ depannya, riset terkait dampak dari penerapan Industri 4.0 juga perlu ditingkatkan sehingga dampak buruk dari kehadirannya dapat diatasi.

\section{DAFTAR PUSTAKA}

Cholid Narbuko dan Abu Achmadi, 2005, Metodologi Penelitian, cet. VI (Jakarta: PT. BumiAksara.

Hamdanunsera. Industri 4.0: Pengaruh Revolusi Industri Pada Kewirausahaan Demi Kemandirian Ekonomi. Jakarta, 2018.

Iqbal Hasan, Metode Penelitian dan Aplikasinya, Jakarta: Ghalia Indonesia, 2002.

Rojko Andreja, Industri 4.0 Concept: Backgound and Overview , 2017

Suharsimi Arikunto, Prosedur Penelitian, Suatu Pendekatan Praktek. (Jakarta: Rineka Cipta, 2002.

Tjandrawinata, R.R, Industri 4.0: Revolusi Industri Abad ini dan Pengaruhnya, 2006.

Zezulka, F., Marcon, P., Vesely, I., \& Sajdl, O. (2016). Industry 4.0-An Introduction in the phenomenon. IFAC-PapersOnLine, Vol. 49, Issue. 25, pp. 8-12.

Zhou, K., Taigang L., \& Lifeng, Z. (2015). Industry 4.0: Towards future industrial opportunities and challenges. In Fuzzy Systems and Knowledge Discovery (FSKD), IEEE 12th International Conference, pp. 2147-2152. 